Mihailo Mrdak ${ }^{1 *}$, Časlav Lačnjevac ${ }^{2}$, Marko Rakin $^{3}$, Đorđe Janaćković ${ }^{4}$, Darko Veljić ${ }^{4}$, Darko Bajić ${ }^{5}$

${ }^{1}$ University of Belgrade, Innovation Center, Faculty of Technology and Metallurgy, Belgrade, Srbija, ${ }^{2}$ University of Belgrade, Faculty of Agriculture, Belgrade,Serbia, ${ }^{3}$ University of Belgrade, Tehnološkometalurški fakultet, Belgrade, Serbia, ${ }^{4}$ University of Belgrade, Innovation Center, Faculty of Technology and Metallurgy, Belgrade, Serbia, ${ }^{5}$ University of Montenegro, Faculty of Mechanical Engineering, R.Montenegro

Scientific paper ISSN 0351-9465, E-ISSN 2466-2585 UDC:669.018.6: 546.82 doi:10.5937/zasmat2001052M

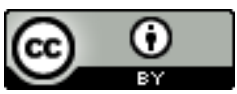

Zastita Materijala 61 (1)

52 - 59 (2020)

\title{
The mechanical and microstructural properties of VPS - Ti porous coating deposited on titanium alloy substrates for osseointegration
}

\begin{abstract}
The topography of the surface of the deposited VPS-Ti coatings on substrate surfaces of implants relating to the roughness and porous structure plays a decisive role in the process of on growth of the implants to the bones i.e.osseointegration. Direct bone on growth has been successfully achieved by using micro rough coating surfaces, such as the use of vacuum plasma spraying VPS - Ti coatings. The aim of this study was to make a comprehensive review of the characterization of porous VPS-Ti coatings deposited on substrates of titanium alloy that will find application in orthopedics. One of the preferred features of the VPS process is the ability to achieve optimum macro and micro structure of the surface of implants by optimizing the spray parameters of the powder deposition and by the range of the powder granulation. In order to achieve an optimum surface roughness, open porosity and structure of VPS-Ti coatings conducted was the optimization of deposition of powder with a change in plasma current and powder carrier gas flow rate of (700 A, 35 l/min and $800 \mathrm{~A}, 20 \mathrm{l} / \mathrm{min}$ ). Lower intensity plasma current with a greater flow of powder heats and melts the powder particles less forming micro pores of a larger size and a higher proportion of open pores and vice versa higher plasma currents and reduced flow provide better melted particles forming a smaller share of micro pores and open porosity in the deposited layers. Image analysis showed that by optimization of parameters in the coatings open porosity can be formed ranging from $45 \%$ to $57 \%$. By examining the properties of the deposited layers it was determined that the most optimal roughness and share of open pores for osseointegration have the Ti layers which have been deposited with the lowest amperage and highest flow of powder carrier gas.
\end{abstract}

Keywords: Osseointegration, VPS-Ti, porosity, bond strength, microstructure.

\section{INTRODUCTION}

The lifespan of the contact surface of bone / implant of the cementless implanted endoprosthesis is mainly determined by the configurationtopography of the implant surface. The optimum structure of the surface which affects the interaction between the bone and the artificial prosthesis can be obtained with a vacuum plasma spray process(VPS). Pure titanium coatings suit alllayer requirements.

\footnotetext{
${ }^{*}$ Corresponding autor: Mihailo Mrdak

E-mail: drmrdakmihailo@gmail.com

Paper received: 11. 11.2019.

Paper accepted: 17. 12. 2019.

Paper is available on the website: www.idk.org.rs/casopis
}

The results of clinical trials indicate that the VPS-Ti coatings have a bioactive effect which allows good on growth (osseointegration) of the implant to the bone. The use of porous coatings is now an subject of considerable interest in the implementation of cementless implanted joint prostheses. The first objective is to increase the surface of the prosthetic part to reduce the surface pressure on the contact surface of the boneimplant. Then, the bone should be able to penetrate deeper into the structure of the prosthesis to improve the mechanical attachment. The criteria are the size of the pores and degree of porosity. Intent to increase the contact area is best achieved by the size of the open pores of not less than $100 \mu \mathrm{m}$. The porous coating on a metal prosthesis creates different requirements for material technology: The material used for the 
prosthesis must be biocompatible and stable in the body. The adhesion between the coating and the surface of the prosthesis must have considerable stress strength during coating deposition. After the bone on growth the coating must not separate. Finally, the mechanical properties of the prosthesis parts that carry the strain must not be damaged by the plasma spray process. The fatigue strength has an important impact on the life span of the implant. Plasma spray processes in vacuum and under atmospheric pressure (VPS and APS), worldwide, have become the dominant technology processes for the production of coatings intended for orthopedic applications in clinical use [1-3]. The advantage of these processes over other technological processes is high superiority when it comes to the reproducibility of the coating quality and economic efficiency of the process. The processes are configured so thata large range of parameters can be modified in order to achieve the designed quality of the coatings. The optimum parameters must be determined for each type of powder, taking into consideration: mean particle size, particle morphology, specific weight, chemical composition and the melting point.

The temperature of the particles in the plasma can be controlled by varying the particle sizes and their physical - chemical properties, powder flow, nature of plasma gases, flow of gases and surrounding pressure. The vacuum plasma spray process allows a wide range of application of powder materials sensitive to oxygen such as $\mathrm{Ti}$, $\mathrm{Ta}, \mathrm{Nb}$, etc. Dense and porous coatings, depending on the requirements, can be deposited by the VPS process. Layers of VPS-Ti coatings can be applied to surfaces of implants made of alloys based on $\mathrm{Ti}, \mathrm{Co}, \mathrm{Cr}$ and $\mathrm{Zr}$. The coatings are biocompatible and have good adhesion strength, surface morphology and thickness of the layers that are required for new structure of orthopedic implants, as they improve the long-term anchoring of the implant in the bone tissue. Porous VPS - Ti coatings are applied to the implant in order to obtain biological fixation and improve the longevity of orthopedic implants. For biological fixation of implants, in the past, used have been different porous metal materials [4]. On growth of bone into the porous surface of the coating is of great importance for long-term success of cementless implants. Stability of integrated or connected implants into a single unit can be achieved, on one handby mechanical blocking of bone tissue and implant surface area (bone ingrowth) and on the other handby direct attachment of the tissue to the surface (ongrowth). At the moment intensive work is being done on expanding the field of new porous materials to expand and improve cementless technology for orthopedic surgery. There are several published studies that evaluated the surface properties of the micro and macro structure of porous titanium implants that cause bone integration. Some of them are disclosed in references [5,6].

The great advantage of porous VPS-Ti coatings is due to biocompatibility which supports normal cellular activity without local and systemic toxic effects on tissues. The coating is osteoconductive and osteoinductive and capable of inducing formation of blood vessels within or around the implants [7]. For the production of coatings on prosthetic implants with very high surface roughness and porosity used are powders of the Oerlikon Metco company marked Metco 4010E (200-350 $\mu \mathrm{m})$, Metco 4010D (90-250 $\mu \mathrm{m})$ and Metco 4010B $(75-180 \mu \mathrm{m})$. These types of coatings are preferred and recommended for biomedical implants because the porous structure promotes bone growth on the implants [8]. At high temperatures, above $882^{\circ} \mathrm{C}$ in the structure of the titanium present is the $\beta$ phase with a centered cubic lattice and with slow cooling below $882^{\circ} \mathrm{C}$ transforms into the a phase with a dense hexagonal crystal lattice. Figure 1 shows the crystal lattice of titanium [9]. When melting the powder particles in the plasma, the liquid phase is cooled quickly so avoiding the $\beta \rightarrow \alpha$ phase transformation, that is why the microstructure of the titanium coating has both phases $(\alpha-\mathrm{Ti}+\beta-\mathrm{Ti})$.

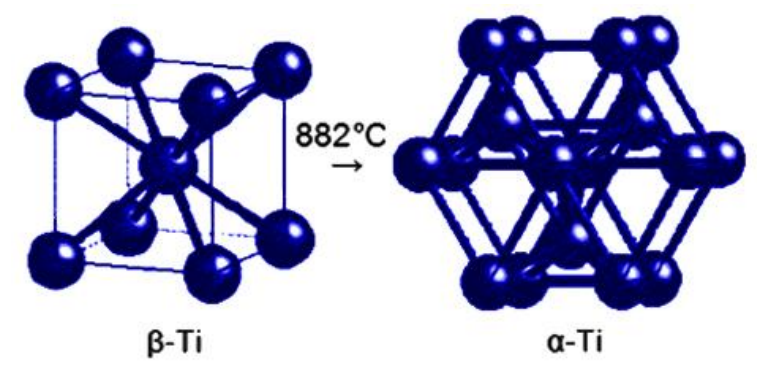

Figure 1. Crystal structures of Ti [9]

Slika 1. Kristalna struktura Ti [9]

Titanium coatings can be used as potential bond coatings for hydroxyapatite coatings that are often used as a top layer on biomedical implants. Titanium powders have a strong affinity and reactivity with oxygen, hydrogen and nitrogen at high temperatures, due to which for the deposition of coatings the protective atmosphere (VPS) processis used.

The aim of this study was to produce porous titanium coating layers which will have application on implant substrates because of their good osseointegration. This can be achieved using the vacuum plasma spray process (VPS), which with a combination of powder deposition parameters 
allows deposition of high-quality porous layers of macro - and microstructure on the substrates, while maintaining high mechanical characteristics values of the coating. This is achieved with a choice of Metco 4010B powder and process parameters relating to the plasma current and powder carrier gas flow rate.

\section{EXSPERIMENTAL PART}

\subsection{Materials and experimental details of plasma spray coatings deposition}

For the deposition of porous coatings $\mathrm{Ti}$ powder marked Oerlikon Metco 4010B was used. The powder contains $99.5 \% \mathrm{Ti}$ and impurities as chemical elements: $\mathrm{Fe}<0.5 \%$; $\mathrm{O}<0.4 \%$; $\mathrm{C}<$ $0.08 \% ; \mathrm{H}<0.015 \%$ and $\mathrm{N}<0.05 \%$ [8]. The melting temperature of the powder is $1649^{\circ} \mathrm{C}$ at a density of $1.8 \mathrm{~g} / \mathrm{cm}^{3}$ to $2.5 \mathrm{~g} / \mathrm{cm}^{3}$, which is intended for the production of coatings that operate in conditions up to $\leq 400^{\circ} \mathrm{C}$. The powder has a wide range of uses in biomedical applications for the preparation of coatings on implants as a separate coating because of good osseointegration as it is biocompatible with living tissue and is resistant to tissue fluid corrosion as well as a bond coating for hydroxyapatite coatings [8]. For obtaining a coating of high porosity applied was a powder with grain size of $75 \mu \mathrm{m}$ to $180 \mu \mathrm{m}$ produced by the technique of melting and grinding of molded blocks. Analysis of the morphology of the powder particles was carried out on a Scanning Electron Microscope (SEM). Figure 2 shows micrographs of the $\mathrm{Ti}$ powder particles in which can be seen that the particles have an irregular shape with rounded and sharp edges.

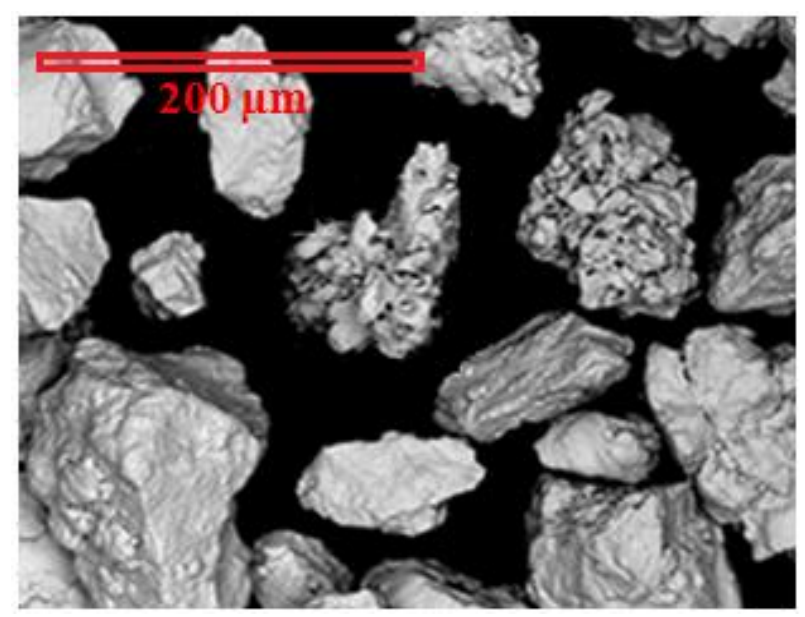

Figure 2. (SEM) Scanning electron micrograph of the Ti powder particles

Slika 2. (SEM) skening elektronska mikrofotografija čestica praha $\mathrm{Ti}$

For the substrate on which titanium coating layers were deposited in order to examine the microhardness, bond strength, and microstructure the material used was the $\mathrm{Ti}$ alloy marked AMS 4928 - 6AL4V. The size of specimens for testing bond tensile strength (adhesion) were rods dimensions of $\varnothing 25.4 \mathrm{~mm} \times 50 \mathrm{~mm}$, and for testing the microhardness and microstructure of layers used were sheets dimensions $70 \times 20 \times 1.5 \mathrm{~mm}$ according to ASTM C633-1 standard [10]. Microhardness testing of $\mathrm{Ti}$ layers was conducted by the $\mathrm{HV}_{0.3}$ method. Microhardness testing was carried out in the direction along the lamellae, in the middle and at the ends of the sample. Five readings were done at three measuring points, and this paper shows the mean value of microhardness. Testing tensile bond strength was carried out at room temperature with a tensile speed of $1 \mathrm{~mm} / \mathrm{min}$. Used were three specimens for each of the two groups of samples (A and B), and the paper shows the mean value. The bond strength of the $\sigma=F / A(\mathrm{MPa})$ coating is calculated as the maximum load $\left(F_{\max }\right)$ on the sample divided by the area $(A)$ of coating fractures [11].

Analysis of porosity in the coatings was carried out by analyzing 5 photos at 200x magnification. The paper shows the mean value of the share of micropores. Microstructural analysis of the coatings on the cross section of samples in deposited state was carried out on an optical microscope (OM). On the scanning electron microscope (SEM), an analysis of the topography was done i.e. surface morphology of the deposited coatings.

Prior to deposition of the $\mathrm{Ti}$ powder in a vacuum chamber roughening of the surface of the substrate was performed with white noble corundum $\left(\mathrm{Al}_{2} \mathrm{O}_{3}\right)$ with particle size of $0.7-1.5$ $\mathrm{mm}$. The aim of the process of roughening of the substrate surface was to create conditions for strong adhesion of the VPS-Ti coatings to the substrate. Special attention was paid to guarantying cleaning the surface of the substrate using a transferred arc prior to the powder deposition process. The second step in the process of making VPS-Ti coatings was depositing a thick bond layer on the substrates for good adhesion and further deposition of porous layers of titanium for osteoconductivity. In this respect the parameters of the plasma spray processes varied relating to changes in plasma currents and changes in the flow rate of plasma gas. Two groups of samples were made, samples (A) on which layers of $\mathrm{Ti}$ coating were deposited with $700 \mathrm{~A}$ and powder carrier gas flow rate of $35 \mathrm{l} / \mathrm{min}$ and samples (B) on which deposited were layers of $\mathrm{Ti}$ coating with $800 \mathrm{~A}$ and powder carrier gas flow rate of $20 \mathrm{l} / \mathrm{min}$. Adjusting the plasma spray parameters and pre-heating the substrate to $400^{\circ} \mathrm{C}$ allowed forming of thick bond layers up to $100 \mu \mathrm{m}$ on the substrate without changing the mechanical 
properties of the substrate. With further deposition of Ti powder on the bond layers without preheating the substrates formed were porous layers with open porosity in order to deposit layers with designed properties. The atmosphere and pressure level in the vacuum chamber are important variables for the plasma spray process because by adjusting these parameters the required quality of coatings can be achieved. When using the vacuum chamber, interaction between the molten powder and the surrounding atmosphere is significantly reduced. This is necessary for $\mathrm{Ti}$ coatings, since $\mathrm{Ti}$ as a material is sensitive to oxidation and absorption of nitrogen. During the VPS process, it is easy to manage melting of the particles, which allows adjustment of the coating porosity while maintaining very good cohesion and adhesion. VPS Ti powder deposition parameters on samples ( $A$ and $B$ ) are shown in Table 1. For deposition of the powder the plasma F4 gun was used.

\section{Table 1. The vacuum plasma spray parameters}

Tabela 1. Vakuum plazma sprej parametri

\begin{tabular}{|l|c|c|c|}
\hline \multirow{2}{*}{ Parameters } & \multicolumn{3}{|c|}{ Value } \\
\cline { 2 - 4 } & $\begin{array}{c}\text { Cleaning } \\
\text { Substrate } \\
\text { arc }\end{array}$ & A & Beposition \\
\cline { 2 - 4 } & 500 & 700 & 800 \\
\hline Plasma current, I (A) & 65 & 45 & 45 \\
\hline Plasma voltage, U (V) & 50 & 33 & 33 \\
\hline $\begin{array}{l}\text { Primarni plazma gas, } \\
\text { Ar (I/min.) }\end{array}$ & 10 & 8 & 8 \\
\hline $\begin{array}{l}\text { Primary Ar plasma } \\
\text { gas flow, } \mathrm{H}_{2}{ }^{1}, \mathrm{He}^{2}, \\
\text { (I/min.) }\end{array}$ & -- & 35 & 20 \\
\hline $\begin{array}{l}\text { Carrier Ar gas flow, } \\
\text { Ar (I/min.) }\end{array}$ & 280 & 300 & 300 \\
\hline Substrate distance, (mm) & 4 & 14 & 14 \\
\hline $\begin{array}{l}\text { Pressure in chamber, } \\
\text { (kPa) }\end{array}$ & 15 & 10 & 10 \\
\hline Nozzle anode, (mm) & 8 & 8 & 8 \\
\hline $\begin{array}{l}\text { Speed plasma gun, (mm } \\
\text { /s) }\end{array}$ & & & \\
\hline
\end{tabular}

On the microprocessor unit of the VPS system Plasma Technik AG robot a program for depositing Ti powder was installed. The program was given all the process parameters that were timesynchronized and related to: venting the chamber, plasma gas flow, cleaning metal substrates with a transferred arc, heating the substrates, powder flow, coating deposition, cooling of metal substrates with a deposited coating and ventilation of the vacuum chamber. Cleaning the surface of metal substrates was done with a gas mixture of Ar- $\mathrm{H}_{2}$ and deposition of the powder with a mixture of plasma gases $\mathrm{Ar}-\mathrm{He}$. The coatings were deposited with a thickness of $600 \mu \mathrm{m}-900 \mu \mathrm{m}$.

\section{RESULTS AND DISCUSSION}

\subsection{Results of coatings testing}

It was discovered that based on the measured values of microhardness and bond strength of the deposited layers that the power of the plasma current and the powder carrier gas flow rate have an impact on the mechanical characteristics. The mean value of microhardness of the bond layers of the VPS - Ti coating along the cross section of sample (A) which were deposited with a low power plasma current and a higher powder carrier gas flow rate was $147 \mathrm{HV}_{0.3}$. With the increase of the plasma current to $800 \mathrm{~A}$ and reduction of the supply of powder, sample (B), the particles have more time to heat through, melt better and therefore be deposited with higher density, which was confirmed by metallographic examination of the coatings. The mean value of microhardness of these layers was $159 \mathrm{HV}_{0.3}$ which is close to the theoretical $\mathrm{Ti}$ hardness. Lower values of microhardness for both the VPS - Ti coatings show that in the coating layers there were no titanium oxides present due to good protection in the vacuum chamber. This was confirmed by analysis of the images on the optical microscope (OM).

The mean value of tensile bond strength of the deposited layers of $\mathrm{Ti}$ with $700 \mathrm{~A}$ and powder carrier gas flow of $35 \mathrm{l} / \mathrm{min}$ was $33.5 \mathrm{MPa}$. For the layers deposited with $800 \mathrm{~A}$ and a lower flow of powder carrier gas of $20 \mathrm{l} / \mathrm{min}$ obtained were greater tensile bond strengths (adhesion) with a mean value of 37.2 MPa. Optimization of the plasma parameters of deposition of $\mathrm{Ti}$ powder in a vacuum chamber provided obtaining layers with a bond strength $>30$ $\mathrm{MPa}$ at high porosity of the coatings. Good adhesion of the coatings with a high share of porosity is the result of good preparation of metal substrates by roughening, cleaning of the substrate surface with a transferred arc and pre-heating the substrates at $400^{\circ} \mathrm{C}$, provided a good bonding of the lower $\mathrm{Ti}$ layers to the surfaces of the substrates. This was confirmed by a qualitative analysis of the bonds of the substrate/ coating on an optical microscope (OM).

Figures 3 and 4 show the microstructure of the VPS-Ti coatings using an optical microscope (OM), which were deposited by changing the plasma current and flow rate of the powder carrier gas (700 A, $35 \mathrm{l} / \mathrm{min}$ and $800 \mathrm{~A}, 20 \mathrm{l} / \mathrm{min}$ ). In the micrographs there are no interfaces between the alloy Ti6Al4V substrates and $\mathrm{Ti}$ coatings, indicating that the boundaries of the interfaces are extremely clean due to good preparation (roughening and cleaning with a transferred arc) as well as preheating the 
metal substrates. The deposited $\mathrm{Ti}$ powder particles at the interface substrate/coating formed characteristically dense bond layers. Therefore, at the interface substrate/coating there are no defects such as interruptions or discontinuations of the deposited layers on metal substrates, micro and macro cracks and separation of the coatings from the metal substrates. Analysis of the interfaces confirms good adhesion of the bond layers with a thickness up to $100 \mu \mathrm{m}$. Through the bond layers of coatings there are no observed inter-lamellar boundaries or micro and macro cracks due to good cohesion bonds of deposited lamellae. The share of porosity in the $\mathrm{Ti}$ coating bond layers is negligible with the share of micropores less than $1 \%$.

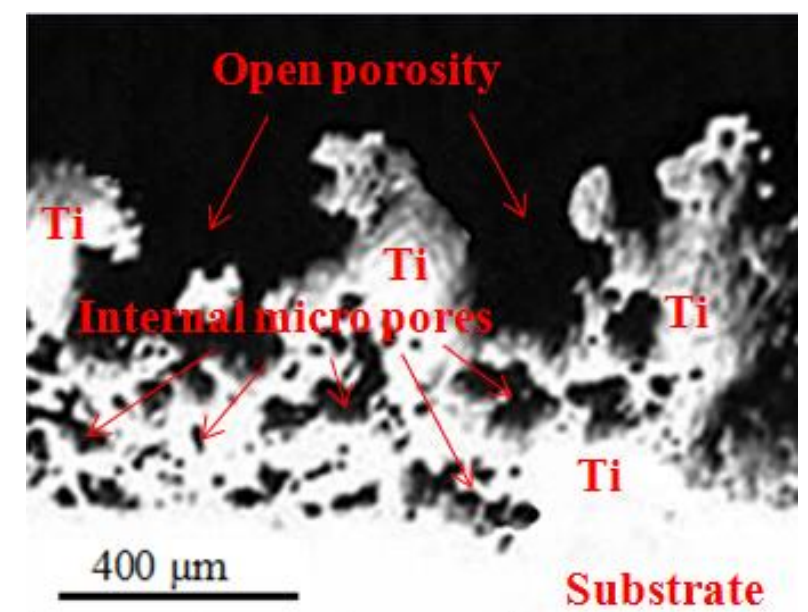

Figure 3. (OM) Microstructure of Ti coatings, 700A and $35 \mathrm{l} / \mathrm{min}$

Slika 3. (OM) mikrostruktura Ti prevlake, 700A and $35 \mathrm{I} / \mathrm{min}$

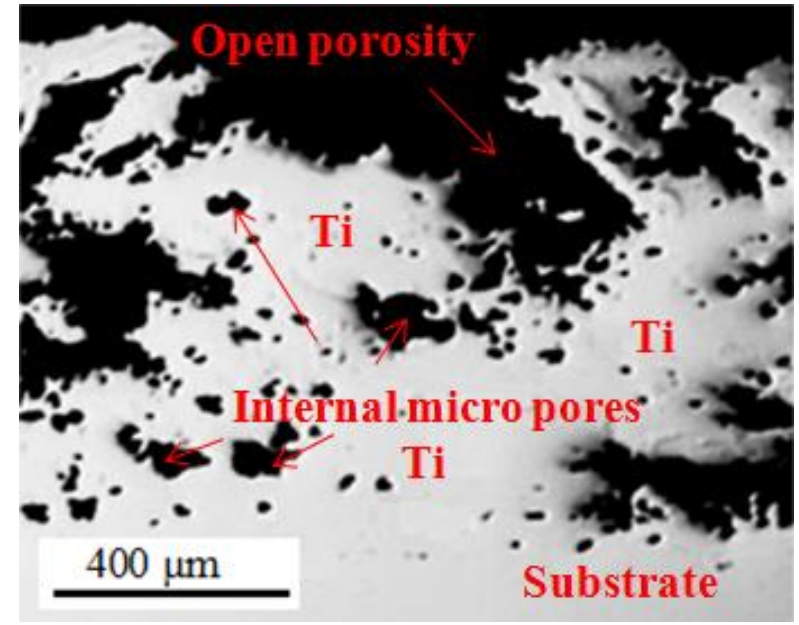

Figure 4. (OM Microstructure of Ti coatings, $800 \mathrm{~A}$ and $20 \mathrm{l} / \mathrm{min}$

Slika 4. (OM) mikrostruktura Ti prevlake, 800A and $20 \mathrm{l} / \mathrm{min}$
Above the dense bond layers formed are porous layers with micro-pores and open pores (voids) up to the coatings surfaces. Open porosity is created by irregular pores which in the process of deposition, due to lower powder melting, interconnect into one unit and in the micrographs are seen as black areas of irregular shape marked by arrows. By analyzing the images of the deposited coatings found is open porosity ranging from $45 \%$ to $57 \%$, depending on the parameters of the deposition of powder. This relatively wide range of porosity depends on the surface which is selected to be measured for the calculation of porosity, because the coatings along the substrate are not homogenous and the open pores are not properly arranged. The cross sections of the VPS$\mathrm{Ti}$ coatings which were deposited on the bond layers with variations of the plasma spray parameters (changing the plasma current and the gas flow) and without pre-heating the substrates show a wide and acceptable range of internal micropores and external open pores. The highest temperature of the plasma jet with $800 \mathrm{~A}$ and lower plasma gas flow rate of $20 \mathrm{l} / \mathrm{min}$ produces coatings with up to $45 \%$ porosity. While lower temperature of the plasma with 700A and higher plasma gas flow rate of $35 \mathrm{l} / \mathrm{min}$, produces a larger proportion of micropores through the layers and larger open porosity (voids) up to $57 \%$ due to the lower melting of powder, which is very convenient for the application of coatings in orthopedics because the porous coatings are more suitable for osseointegration.

Since Ti crystallizes into two crystalline forms, $\alpha-\mathrm{Ti}$ in a hexagonal close-packed lattice and $\beta-\mathrm{Ti}$ in a spatially centered cubic lattice, it is expected that both phases are present in the microstructure of the deposited coating. After partial melting of the $\mathrm{Ti}$ powder particles in the plasma, the molten portion hardens rapidly with a high cooling rate which is why the high-temperature $\beta$ - Ti phase is maintained at room temperature in the structure of the coating. The structure of the coating consists of the starting $\alpha-\mathrm{Ti}$ in the powder which is located in the unmelted powder particles cores which serve as centers for crystallization of the $\beta$ - Ti phase.

In Figures 5 and 6 are (SEM) micrographs showing the typical locations with the most rigid surface morphology (topography) of VPS-Ti coatings deposited on alloy Ti6Al4V substrates. Because of osseointegration surface topography of coatings plays an important role defined in terms of texture and surface roughness. Osseointegration is the process of on growth of the implant into the bone. When inserting the implant the bone cells regenerate, creating a strong bond with its surface, similar to the natural root. Therefore, it is necessary to define the topography of the surface as well as 
the macrostructure (at the millimeter level) for the short term primary mechanical anchoring of the implant as well as the microstructure (at the submicrometerlevel) for long-term stability. The interaction of cells with the implants takes place at the sub-micrometer level. Some studies prove that the anisotropic structure considerably improves the integration of the bone [12,13]. Micrographs of the coating show a rough and porous topography that is formed by the accumulation of coarse incompletely melted Ti powder particles.

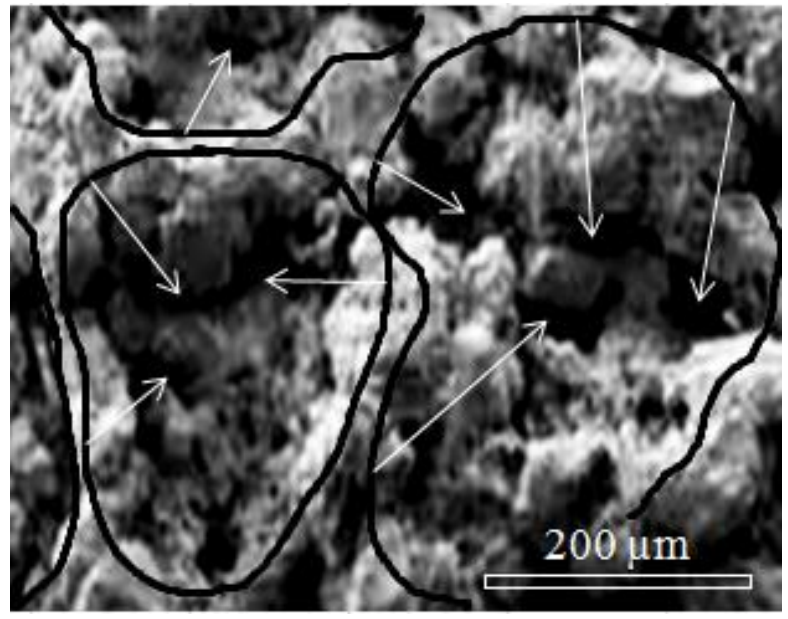

Figure 5. (SEM) Surface morphology of Ti coatings, $700 \mathrm{~A}$ and $35 \mathrm{l} / \mathrm{min}$.

Slika 5. (SEM) morfologija površine Ti prevlake, $700 \mathrm{~A}$ and $35 \mathrm{l} / \mathrm{min}$.

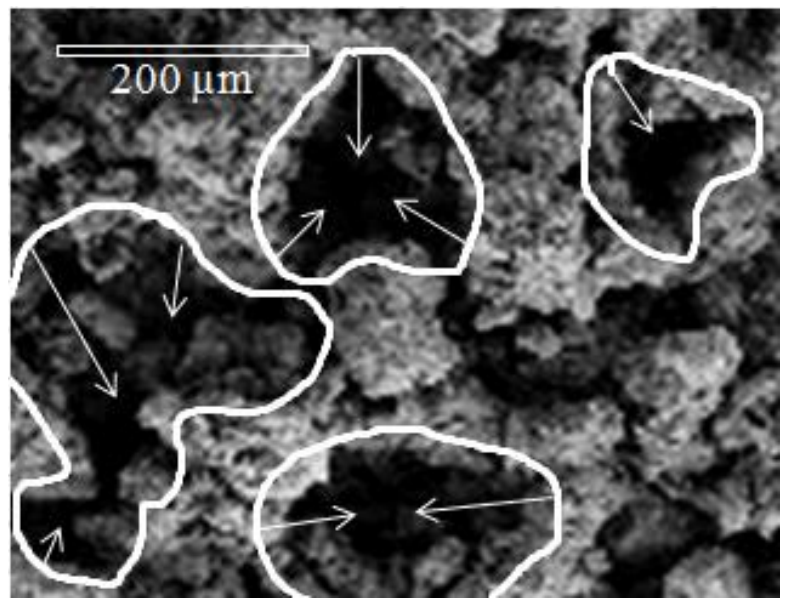

Figure 6. (SEM) Surface morphology of Ti coatings, $800 \mathrm{~A}$ and $20 \mathrm{l} / \mathrm{min}$

Slika 6. (SEM) morfologija površine Ti prevlake, $800 \mathrm{~A}$ and $20 \mathrm{l} / \mathrm{min}$.

Open porosity is created exclusively by irregular pores, which are formed by deposition of incompletely melted powder particles and connecting in a single form. Figure 4 shows the surface of the VPS-Ti coating deposited with 700A and powder carrier gas flow of $35 \mathrm{l} / \mathrm{min}$, which is characterized by a very coarse and random (intermittent) anisotropic porous structure. Micrographs show coarse pores of irregular shape, which extend from the surface in depth toward the inner coating layers with a pore size distribution between $400 \mu \mathrm{m}$ and $500 \mu \mathrm{m}$. Propagation of pores from the surface to the inner layers, are marked with arrows.

Figure 5 shows the surface of the VPS-Ti coating deposited with $800 \mathrm{~A}$ and powder carrier gas flow of $20 \mathrm{l} / \mathrm{min}$, which is also characterized by an anisotropic porous structure, but with a smaller size of open pores.

Coarse open porosity has an irregular shape that extends in depth from the surface toward the inner coating layers with a pore size distribution between $180 \mu \mathrm{m}$ and $380 \mu \mathrm{m}$. In the micrographs the arrows show the propagation of pores from the surface to the inner layers of the coating.

In the (SEM) and (OM) micrographs clearly observed, in a greater proportion, are internal micropores small in size, $10 \mu \mathrm{m}$. Taking into account the present micro and macropores, pore size range in the deposited coatings was from 10 $\mu \mathrm{m}$ to $500 \mu \mathrm{m}$. Irregular geometry of open macropores as well as inner micropores which are ideal for osseointegration, make it difficult to define the mean size of the pores.

However, using the method of medium-length of the cross-section of the voids defined by ASTM F 1854 standard, the measured mean pore size was in the range from $110 \mu \mathrm{m}$ to $170 \mu \mathrm{m}$, which completely corresponds to the requirement for optimized interaction between the implant coating and cells [14]. Biomedical VPS-Ti coatings should have rough pores, size $>100 \mu \mathrm{m}$ that must be interconnected to ensure good bonding of the implant with the bone [15].

\section{CONCLUSIONS}

In this study, by optimizing the vacuum plasma spray parameters, deposited were porous layers of VPS-Ti coatings on Ti6AI4V alloy substrates, to homologize and develop coatings which will correspond to the biological requirements for interaction of the cellular implants. Analyzed were the mechanical properties, microstructure of the coatings using (OM) microscopy and surface topography of coatings in deposited state on the (SEM) microscope, based on which the following conclusions were made.

Roughing and cleaning of the substrate surfaces with a transferred arc and preheating of the substrates made it possible to deposit the bond 
layers with mean values of microhardness of 147 $\mathrm{HV}_{0.3}$ and $159 \mathrm{HV}_{0.3}$. Slightly higher microhardness of the bond coating deposited with higher plasma current of $800 \mathrm{~A}$ and lower powder flow of $20 \mathrm{l} / \mathrm{min}$ is expected for better melting of the powder particles. The bond strengths were correlated with the parameters of the powder deposition. Higher amperage, $800 \mathrm{~A}$ and lower powder carrier gas flow rate of $20 \mathrm{l} / \mathrm{m}$ for melting and constructing of bond layers with the porous layers enabled deposition of thicker bond layers than those which have been deposited with 700A and powder carrier gas flow of $35 \mathrm{l} / \mathrm{min}$. Good adhesion > $30 \mathrm{MPa}$ of coatings with a high proportion of porosity was achieved by good preparation of metal substrates with pre-heating at $400^{\circ} \mathrm{C}$.

The analysis of the micrographs of deposited coatings established open porosity with a different percentage of pores depending on the powder deposition parameters. Coatings deposited with $800 \mathrm{~A}$ and plasma gas flow rate of $20 \mathrm{l} / \mathrm{min}$ had a porosity of $45 \%$. Lower plasma current of $700 \mathrm{~A}$ and a higher flow rate of plasma gas of $35 \mathrm{l} / \mathrm{min}$ deposited layers with an open porosity of $57 \%$ as a result of lesser powder melting. The structure of the coating consists of the starting $\alpha-\mathrm{Ti}$ in the powder which is located in the unmelted cores of the powder particles that served as the centers of crystallization and $\beta$ - Ti phase formed by rapid cooling of the liquid phase.

Analysis of the surface topography of deposited coatings displayed in the (SEM) micrographs showed that the VPS-Ti coatings deposited with $700 \mathrm{~A}$ and powder carrier gas flow of $35 \mathrm{l} / \mathrm{min}$ have a coarse porous anisotropic structure.

Present on the surface are open coarse pores of irregular shape, which extend from the surface toward the inner coating layers in a range from 400 $\mu \mathrm{m}$ to $500 \mu \mathrm{m}$. VPS-Ti coatings deposited with $800 \mathrm{~A}$ and powder carrier gas flow of $20 \mathrm{l} / \mathrm{min}$ also have open porosity of irregular shape with a range of pores from $180 \mu \mathrm{m}$ to $380 \mu \mathrm{m}$. The range of sizes of pores present in the deposited coatings was from $10 \mu \mathrm{m}$ to $500 \mu \mathrm{m}$. Using the method of medium-length cross-section of the voids defined by ASTM F 1854 standard, the measured mean pore sizes in both coatings were in the range from $110 \mu \mathrm{m}$ to $170 \mu \mathrm{m}$, which completely corresponds to the requirement for the optimized interaction between the implant coating and cells.

The aim of this study was achieved by application of the (VPS) process and combination of the powder deposition parameters. High quality porous layers of VPS-Ti coatings were deposited and they had good mechanical properties and microstructure with an open porosity of $>100 \mu \mathrm{m}$, which provides proper bonding and on growth of bone into the porous surface of the implant coating.

\section{Acknowledgement}

This investigation was supported by Serbian Ministry of Education, Science and Technological Development (national projects Ol174004 \& TR34016).

\section{REFERENCE}

[1] M.Mrdak, Č.Lačnjevac, M.Rakin (2018) Mechanical and structural features of $\mathrm{Nb}$ coating layers deposited on steel substrates in a vacuum chamber, Zastita materijala 59(2), 167-172.

[2] M.Mrdak, Č.Lačnjevac, M.Rakin, N.Bajić (2018) Characterization of tantalum coatings deposited using vacuum plasma spray process, Zastita materijala 59(4), 489-494.

[3] M.Mrdak, Č.Lačnjevac, M.Rakin, N.Bajić, D.Veljić (2019) Karakterizacija plazma sprej bioinertne prevlake $\mathrm{Al}_{2} \mathrm{O}_{3} 28$ tež.\%MgO, Zastita materijala 60(1), 44-49.

[4] DW.Fabi, BR.Levine (2012) Porous Coatings on Metallic Implant Materials. ASM Handbook, Volume 23: Materials for Medical Devices, p.307-319.

[5] G.Altankov, F.Grinnell, T.Groth (1996) Studies on the biocompatibility of materials: Fibroblast reorganization of substratum-bound fibronectin on surfaces varying in wettability. Journal of Biomedical materials research 30(3), 385-391.

[6] CF.Wertz, M.M.Santore (2001) Santore Effect of surface hydrophobicity on adsorption and relaxation of kinetics of albumin and fibrinogen: single-species and cpmpetitive behaviour. Langmuir 17(10), 30063016.

[7] S.Bose, M.Roy (2012) Bandyopadhyay A. Recent advances in bone tissue engineering scaffolds, Trends Biotechnology, 30(10), 546-554.

[8] O.Metco (2017) Material Product Data Sheet, Pure Titanium and Titanium Alloy Powders Thermal Spray Powders. DSMTS-0089.5.

[9] ASMI Handbook (1994) Materials Properties Handbook: Titanium Alloys.

[10] ASTM C633-1 (2008) Standard Test Method for Adhesion or Cohesion Strength of Thermal Spray Coatings, Reapproved.

[11] M.Mrdak, N.Bajić, D.Veljić, M.Rakin, J.Pekez, Z.Karastojković (2016) Testing adhesive bond strength and fracture mechanisms of thicker and porous plasma spray coatings, VI International Conference Industrial Engineering and Environmental Protection 2016 (IIZS 2016), University of Novi Sad, Technical faculty "Mihajlo Pupin" Zrenjanin, p.249-253.

[12] S.Chen, JA.Jones, Y.Xu, HY.Low, JM.Anderson, KW.Leong (2010), Characterization of topographical effects on macrophage behaviour in a foreign body response model, Biomaterials 31(13), pp.34793491. 
[13] E.Mariani, G.Lisignoli, R.M.Borzì, L.Pulsatelli (2019) Biomaterials: Foreign Bodies or Tuners for the Immune Response?, International Journal of Molecular Sciences, 20(3), 636.

[14] ASTM F1854: (2009) Standard test method for stereological evaluation of porous coating on medical implants. West Conshohocken, PA: ASTM International.

[15] W.Winkler-Gniewek (1989) Die PlasmaporeBeschichtung für die zementlose Verankerung von Gelenkendoprothesen, Tom 22 knjige Wissenschaftliche Informationen, Vormals Jetter und Scheerer (Tuttlingen). Aesculap-Werke AG.

\title{
IZVOD
}

\section{MEHANIČKA I MIKROSTRUKTURNA SVOJSTVA VPS - Ti POROZNE PREVLAKE DEPONOVANE NA PODLOGAMA OD LEGURE TITANA ZA OSTEOINTEGRACIJU}

\begin{abstract}
Topografija površine deponovanih VPS-Ti prevlaka na podlogama implanata koja se odnosi na hrapavost i poroznu strukturu imaju odlučujuću ulogu u procesu srastanja implanata sa kostima odnosno osteointegraciju. Direktno urastanje kostiju uspešno se postiže korišćenjem mikro grubih površina prevlaka, kao što je primena vakuum plazma sprej VPS - Ti prevlake. Cilj ovog rada je bio da se napravi sveobuhvatan pregled karakterizacija VPS-Ti poroznih prevlaka deponovanih na podlogama od legure titana koje će naći aplikaciju u ortopediji. Jedna od povoljnih osobina VPS procesa je mogućnost postizanja optimalne makro i mikro strukture površine implanata optimizacijom sprej parametara depozicije praha i rasponom granulacije praha. U cilju postizanja optimalne hrapavosti, otvorene poroznosti i strukture VPS-Ti prevlaka sprovedena je optimizacija depozicije praha sa promenom plazma struje i protokom nosećeg gasa praha (700 A, $35 \mathrm{I} / \mathrm{min} i$ 800A, 20 l/min). Niža jačina plazma struje uz veći protok praha slabije progreva $i$ topi čestice praha obrazujući mikro pore veće veličine $i$ veći udeo otvorenih pora i obrnuto veća plazma struja $i$ manji protok omogućuju bolje topljenje čestica uz formiranje manjeg udela mikro pora $i$ otvorene poroznosti u deponovanim slojevima. Analizom slika ustanovljeno je da se sa optimizacijom parametara u prevlakama može formirati otvorena poroznost sa rasponom od $45 \%$ do $57 \%$. Ispitivanjem karakteristika deponovanih slojeva ustanovljeno je da najoptimalniju hrapavost $i$ udeo otvorenih pora za osteointegraciju imaju slojevi Ti deponovani sa najnižom amperažom i najvećim protokom nosećeg gasa praha.
\end{abstract}

Ključne reći: osteointegracija, VPS-Ti, poroznost, čvrstoća spoja, mikrostruktura.

Naučni rad

Rad primljen: 11. 11. 2019.

Rad prihvaćen: 17. 12. 2019.

Rad je dostupan na sajtu: www.idk.org.rs/casopis

(C) 2020 Authors. Published by Engineering Society for Corrosion. This article is an open access article distributed under the terms and conditions of the Creative Commons Attribution 4.0 International license (https://creativecommons.org/licenses/by/4.0/) 